\title{
Accurate and rapid novel genetic diagnosis for detection of sentinel lymph node metastasis in breast cancer patients
}

\author{
H linuma', J Tamura', D Omoto², N Kamo', S Ohnaka ${ }^{2}$, Y Mitoma ${ }^{2}$, Y Miyazawa ${ }^{3}$, K Okinaga', T Imamura $^{4}$, \\ R Fukushima', T Watanabe' and T Ikeda' \\ 'Department of Surgery, Teikyo University School of Medicine, Tokyo 173-0003, Japan; ${ }^{2}$ Bioscience Division, TOSOH Corporation, Kanagawa 252-I I 23, \\ Japan; ${ }^{3}$ Department of Clinical Laboratory Medicine, Faculty of Medical Technology, Teikyo University, Tokyo I 73-0003, Japan; ${ }^{4}$ Department of Clinical \\ Pathology, Teikyo University School of Medicine, Tokyo 173-0003, Japan
}

BACKGROUND: The transcription-reverse transcription concerted reaction (TRC) test is a novel molecular-based procedure, which can assess nodal metastasis accurately and quickly. We examined the usefulness of the TRC test with a double marker, cytokeratin 19 (CKI9) and carcinoembryonic antigen (CEA) mRNA, to detect sentinel lymph nodes (SLN) metastasis in breast cancer patients. METHODS: A total of 264 SLNs from 13I breast cancer patients were assigned to a training set (I09 SLNs from 50 patients) and validation set (I55 SLNs from 8I patients). Cytokeratin 19 and CEA mRNA were detected by TRC tests, and the sensitivity and specificity of the SLN metastasis between the TRC and histology cohorts were compared.

RESULTS: Mean copy numbers of CKI 9 and CEA by TRC tests were increased according to the metastatic size. In the training set, TRC test showed 100\% sensitivity, specificity and concordance rates against the permanent histopathology test. In the validation set, sensitivity was $97.1 \%$, specificity was $99.2 \%$ and the concordance rate was $99.4 \%$.

CONCLUSION: Our results showed that the detection of CKI9 and CEA mRNA using the TRC test is, an accurate and rapid method for detection of SLN metastasis and can be applied as an intraoperative molecular diagnosis in breast cancer patients.

British Journal of Cancer (2012) 1 07, 724-73I. doi:I0.1038/bjc.2012.300 www.bjcancer.com

Published online 10 July 2012

(c) 2012 Cancer Research UK

Keywords: TRC; breast cancer; sentinel lymph node; metastasis; CK 19; CEA

Axillary lymph node status is one of the most important prognostic factors for breast cancer patients (Fisher et al, 1993). The sentinel lymph node (SLN) is highly predictive for the status of the remaining axillary lymph node (Veronesi et al, 2003, Ferrari et al, 2006). As the SLN biopsy is a minimally invasive technique, it has readily evolved into the most up-to-date standard staging procedure in patients with clinically lymph node-negative early stage breast cancer (Lyman et al, 2005; Purushortham et al, 2005; Kim et al, 2006; Mansel et al, 2006). Current guidelines recommend completion axillary lymph node dissection (CALND) for patients with SLN metastases (NCCN, 2011). This procedure is considered valuable in achieving regional control, identifying the tumour spread and obtaining accurate nodal staging for the selection of adjuvant chemotherapy and radiation therapy (Moore and Kinne, 1997).

Recently, the American College of Surgeons Z0011 randomised clinical trial has found that axillary dissection is not necessary for survival or local control in the context of breast-conserving surgery with whole breast irradiation and systemic therapy. However, careful consideration is required in the evaluation of this study when it comes to patient as the number of patients enrolled in this trial was limited, and there were only a few patients with poor prognosis who had >3-positive SLN. The Z0011 trial has a potential role for avoiding CALND in a selected and limited

*Correspondence: Dr H linuma; E-mail: iinuma@med.teikyo-u.ac.jp Received 9 March 2012; revised 12 June 2012; accepted I5 June 2012; published online 10 July 2012 group of SN-positive patients, but the eligibility criteria and the role of systemic adjuvant therapies need to be elucidated further (Giuliano et al, 2011).

For evaluation of SLN, first intraoperative detection by conventional hematoxylin and eosin (H\&E) histopathological examination of frozen sections is achieved, and then definitive postoperative histopathological examination by $\mathrm{H} \& \mathrm{E}$ and immunohistochemial (IHC) staining of permanent sections performed (Cote et al, 1999; Torrenga et al, 2001). However, the H\&E histopathological examination of single section suffers from a rather low sensitivity (Tanis et al, 2001). Although the falsenegative diagnosis of SLNs can be reduced by serial sectioning with IHC staining, this procedure requires a substantial investiment of both time and money (van Diest et al, 1999). If the postoperative histological examination proves to be positive, patients are subjected to adjuvant lymph node dissection in a second surgery, which causes discomfort for the patients. Therefore, the development of a precise and objective intraoperative method for detection of SLN is important if we are to increase the accuracy of breast cancer surgery navigated with SLN.

To overcome the problems associated with conventional histopathological methods, molecular detection of metastasis based on a quantitative reverse transcription-PCR (QRT-PCR) assay has been developed (Weigwlt et al, 2004; Nissan et al, 2006). Recently, we developed a novel rapid quantitative genetic assay based on the transcription-reverse transcription concerted (TRC) reaction system (Fujiwara et al, 2007; Hayama et al, 2007; Ohashi et al, 2007). This method allows direct RNA amplification at a constant temperature without need for the three steps of thermal 
cycling. These advantages should facilitate rapid diagnosis, which could be applied for intraoperative diagnosis of SLN in breast cancer. However, because the development of a commercially available TRC reagent for cancer metastasis was only for the detection of carcinoembryonic antigen (CEA) mRNA, until now this system could not be applied to SLNs metastasis in breast cancer patients.

In this study, we first developed a novel reagent to detect CK19 mRNA in the TRC assay. Next, we used this assay for intraoperative rapid diagnosis of SLN with metastasis in breast cancer patients and examined the sensitivity and specificity of the TRC assay with double markers (CK19, CEA) in comparison with the histopathological diagnosis.

\section{PATIENTS AND METHODS}

\section{Clinical study protocol}

This study was approved by the ethical committee of Teikyo University, and all patients provided written informed consent. A total of 264 SLNs from 131 breast cancer patients with early stage disease were included. The study consisted of a sequential training set and a validation set. The first 109 SLNs from 50 patients were enrolled as a prospective training set between May 2007 and May 2008 , and cutoff values of CK19 and CEA mRNA were determined by analysing receiver operating characteristic (ROC) curves on the basis of the mRNA levels of these markers and histopathological results. The ability of these genetic markers to diagnose the metastasis of SLN on the basis of the predetermined cutoff values was then evaluated in the subsequent prospective validation set, which enrolled 155 SLNs from 81 patients between June 2008 and April 2010.
Rapid genetic diagnosis of SLN metastasis in breast cancer $\mathrm{H}$ linuma et al

\section{Detection of metastasis of SLN}

The SLN samples were determined by a combination of RI (99mTc phytate), isosulfan blue dye and indigocarmine intraoperatively, and were collected for histopathological examination and molecular detection by TRC. As shown in Figure 1A, fresh lymph nodes were divided into two blocks, and then seven serial sections were cut from the cutting surfaces. Five sections with $5 \mu \mathrm{m}$ thickness were cut for histopathological study and two sections with $15 \mu \mathrm{m}$ thickness were cut for TRC assay. The sections of no. 1 and no. 3 were used for quick intraoperative histopathological examination, slices no. 2 and no. 4 were used for the TRC assay, and no. 5, no. 6 and no. 7 were used for the permanent section. As for the intraoperative histopathological study, $\mathrm{H} \& \mathrm{E}$ staining was performed. In the permanent histopathological study, H\&E staining and IHC staining using the anti-human cytokeratin-multi AE1/AE3 mouse mAb (CK1-8/10/14/15/16/19; Dako, Tokyo, Japan) and antihuman CEA mouse monoclonal antibodies (Dako) were examined in each sample. Metastases were classified according to the tumour-node metastasis (TNM) classification of the UICC 6th and AJCC 6th edition, and lymph nodes with ITC were considered negative.

\section{Transcription-reverse transcription concerted reaction reaction}

The principle of direct amplification of CK19 and CEA mRNA by TRC is schematically represented in Figure $1 \mathrm{~B}$. A scissor probe is used to initiate TRC reaction and the promoter and antisense primers are the pair of primers for amplification. An interactionactivating fluorescence (INAF) probe is used to detect the mRNA amplification. The sequences of the primers, scissor probes and INAF probes are listed in Supplementary Table 1.

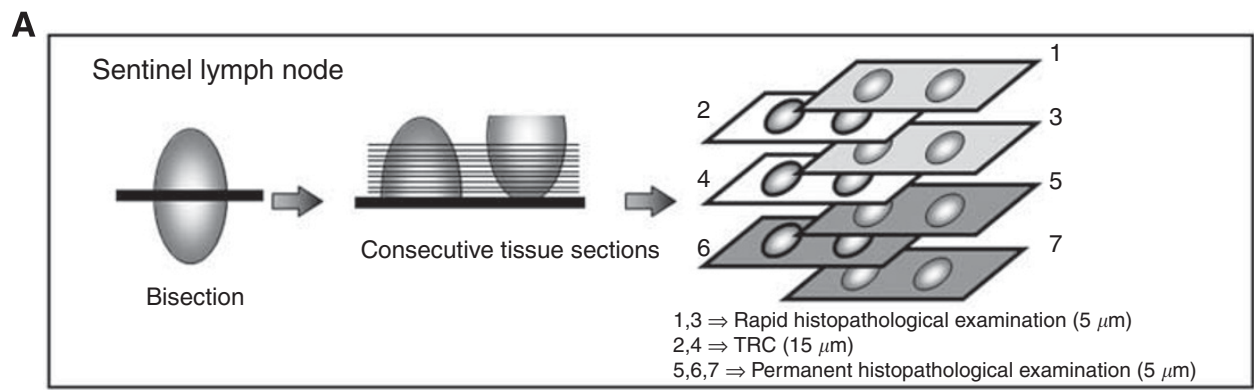

B

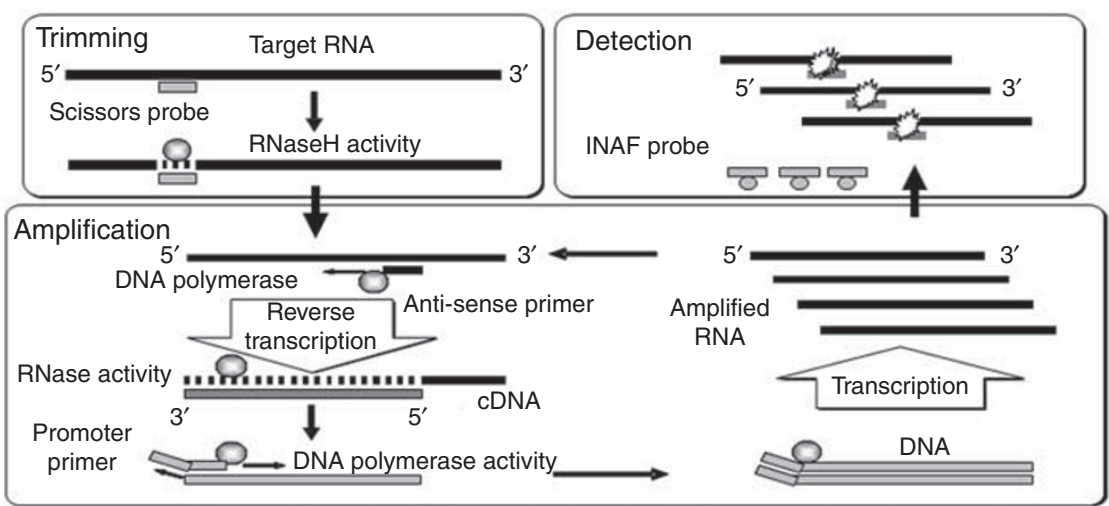

Figure I Preparation of SLN sections and principles of the TRC test. (A) Preparation of SLN sections for the TRC and pathological tests is shown. In the continuous histological section of SLN, no. I and no. 3 sections were prepared for rapid histopathological examination using the H\&E staining. No. 2 and no. 4 sections were prepared for the TRC method and CKI9, CEA and PBGD (internal control) mRNA were measured by TRCRapid- 160. No. 5, no. 6 and no. 7 sections were prepared for permanent histopathological examination by the H\&E staining and IHC staining of cytokeratin and CEA. (B) Principles of the TRC test are summarised. The TRC reaction consists of a sequence of steps including trimming of mRNA with scissor probe and RNaseH activity of reverse transcriptase (RT), complementary DNA synthesis with RT, double-stranded DNA (dsDNA) synthesis by DNA polymerase activity of RT and subsequent transcription (mRNA amplification) of promoter-bearing dsDNA with T7 RNA polymerase. Detections of amplified CEA or CKI9 mRNA are achieved with a gene-specific INAF hybridisation probe. 
Total RNA was extracted using an RNAeasy Mini Kit (Qiagen, Valencia, CA, USA) in accordance with the procedure of manufacturer. Transcription-reverse transcription concerted reaction was measured according to the protocol provided by the manufacturer of the CEA TRCR test (Tosoh Corp., Kanagawa, Japan). As target genes of breast cancer, CK19 and CEA mRNA were selected and porphobilinogen deaminase (PBGD) mRNA was used as a housekeeping gene. The procedure of the TRC test was as follows. In the PCR tube, $20 \mu \mathrm{l}$ of TRC buffer was added to $5 \mu \mathrm{l}$ of the RNA extract, followed by an additional $5 \mu$ l of the enzyme mix. The tube containing the mixture was closed and set in a TRC monitor (TRCRapid-160; Tosoh Corp.), to measure the fluorescence intensity of the reaction mixture incubated at $43^{\circ} \mathrm{C}$. They were assembled into one unit to enable synchronous scanning of the fluorescence while the tube was irradiated. The light-emitting diode turns like a beacon to irradiate the excitation light $(470 \mathrm{~nm})$ into a tube from the outside. The fluorescence $(520 \mathrm{~nm})$ is transferred from the bottom of the tube through a light guide. All samples were measured in duplicate. The mRNA in each sample was quantified automatically with reference to the standard curve of the positive control, as determined by the TRC software (Tosoh Corp.). Porphobilinogen deaminase was used to check the quality of the RNA from the SLN samples.

\section{Sensitivity tests of TRC assay}

First, sequentially diluted CK19 RNA synthesised in vitro (CK19 standard RNA, from 50 to $3 \times 10^{5}$ copy) and CEA standard RNA (from 50 to $1 \times 10^{5}$ copy) were used for a sensitivity test of the TRC assay. Next, sequentially diluted CK19 and CEA-positive breast cancer cell line MCF7 (from 10 to $10^{3}$ cells) were mixed with peripheral blood mononuclear cells (PBMC; $10^{7}$ cells) obtained from healthy volunteers, and TRC assays for CK19, CEA and PBGD were performed as described above. These experiments were performed in duplicate. Breast adenocarcinoma MCF7 cell line was obtained from the Cancer Cell Repository of Tohoku University (Sendai, Japan). Cells were cultured in RPMI1640 medium supplemented with 10\% foetal calf serum and $1 \%$ penicillin and streptomycin (Invitrogen Corp., Carlsbad, CA, USA) at $37{ }^{\circ} \mathrm{C}$ in $5 \% \mathrm{CO} 2$ atmosphere.

\section{Statistical analysis}

Sensitivity, specificity and concordance rates were determined by comparing the results of the TRC assay and pathological examination (intraoperative and permanent pathological tests). Data were analysed using JMP V 7.0 software (SAS Institute Inc., Cary, NC, USA).

\section{RESULTS}

\section{Sensitivity and specificity of the reagents for the TRC assay}

In order to enable a comparison with the commercially available TRC CEA Kit, the reagent for CK19 mRNA has been newly developed for this study. We first examined the sensitivity of this reagent using the CK19 standard RNA (Figure 2A). In the test using the serial dilution of CK19 standard RNA (from 50 to $3 \times 10^{5}$ copy), the working curve showed a straight line. This demonstrated the quantity of this assay $(\gamma=0.999)$. In the examination of the CEA reagent, almost the same sensitivity (from 50 to $1 \times 10^{5}$ copy) was demonstrated $(\gamma=0.997)$ (Figure 2B). Next, we examined the sensitivity of the CK19 and CEA mRNA reagent using the MCF7 breast cancer cell line. In the detection of CK19 and CEA mRNA, MCF7 cells mixed with $10^{7} \mathrm{PBMC}$ were detectable from at least 10 tumour cells, showing up as straight lines of working curves $(\gamma=0.998$ in CK19 and $\gamma=0.999$ in CEA) (Figure $2 \mathrm{C}$ and $\mathrm{D})$. Although we examined the specificity of TRC regents for CK19 mRNA using the standard samples of CK1-8 and CK20
RNA, significant amplifications were not detected (data not shown).

These results suggest high sensitivity (1 tumour cell in $10^{6}$ PBMC) and specificity of the CK19 and CEA TRC reagents.

\section{Patients' characteristics}

Our clinical study consisted of sequential training and validation sets. Patient clinicopathological characteristics and cancer history for the training and validation studies are shown in Table 1. In a comparison of age, sex, menopausal status, primary tumour, histological type and stage, there were no significant differences between these two groups.

\section{Histopathological study}

Histopathological diagnosis was undertaken in two ways: intraoperative rapid diagnosis using H\&E staining for frozen sections, and postoperative diagnosis using $\mathrm{H} \& \mathrm{E}$ and IHC staining for permanent sections. Supplemental Table 2 shows a comparison of these tests in serial sections from the same block. The metastasispositive rates were $11.0 \%(29 / 264)$ in the intraoperative diagnosis and $17.4 \%(46 / 264)$ in the permanent diagnosis. Both positive SLNs of intraoperative and permanent diagnosis were $63.0 \%(29 / 46)$, and both negative SLNs were $100.0 \%$ (218/218). The overall concordance rate between the intraoperative and permanent diagnosis was $93.6 \%$ (247/264). There were 17 false-negative SLNs in intraoperative diagnosis, and these results may indicate the low sensitivity of the intraoperative pathological diagnosis.

\section{Cutoff of CK19 and CEA mRNA}

Using the training set, cutoff values for CK19 and CEA mRNA were predetermined, and these levels were then validated in the subsequent validation set. From the results of the ROC curve of the training set, cutoff levels were decided at 61 copies for CK19 mRNA and 329 copies for CEA mRNA (data not shown).

\section{Transcription-reverse transcription concerted reaction $v s$ histopathology}

Figure 3 shows the differences in the copy numbers of the CK19 and CEA mRNA after the TRC tests according to the classification of metastasis. In this study, 4 ITC cases, 10 micrometastases cases and 36 macrometastases cases were observed by permanent histopathological testing. The mean copy numbers $( \pm$ s.d.) of CK19 mRNA were $2.8 \pm 6.7$ in metastasis-free, $19.8 \pm 23.2$ in ITC, $1377.2 \pm 2384.3$ in micrometastais and $89237.6 \pm 163620.8$ in macrometastases cases. In the CEA mRNA, they were $14.8 \pm 49.7$ in metastasis-free, $18.3 \pm 22.9$ in ITC, $536.0 \pm 835.3$ in micrometastases and $95030.8 \pm 235145.3$ in macrometastases cases. Mean copy numbers of CK19 and CEA mRNA increased significantly according to the metastatic size. There were no significant differences in copy numbers between the metastasis-free and the ITC group. These results show that increases in the copy number of CK19 and CEA mRNA after TRC are associated with the size of the metastasis of SLN.

Table 2 shows the sensitivity, specificity and concordance rates of CK19, CEA and CK19 and/or CEA (CK19/CEA) mRNA levels by TRC tests against the intraoperative and permanent pathological tests. In comparison with the intraoperative diagnosis of the training set, the CK19 single marker group showed high sensitivity $(100 \%)$ and specificity (98.0\%), with levels almost the same as those of the CK19/CEA double marker group (100\% sensitivity, 96.1\% specificity) (Table 2A). However, the CK19 single marker showed a lower sensitivity (81.8\%) than CEA/CK19 (100.0\%) in comparison with the permanent pathological test, which is known as the 'gold standard'. The CEA single marker also showed low 
A

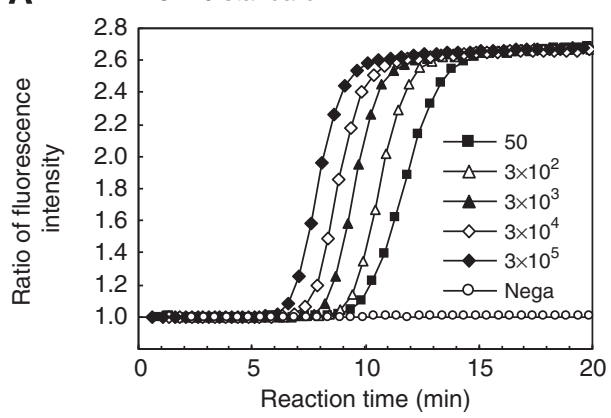

B

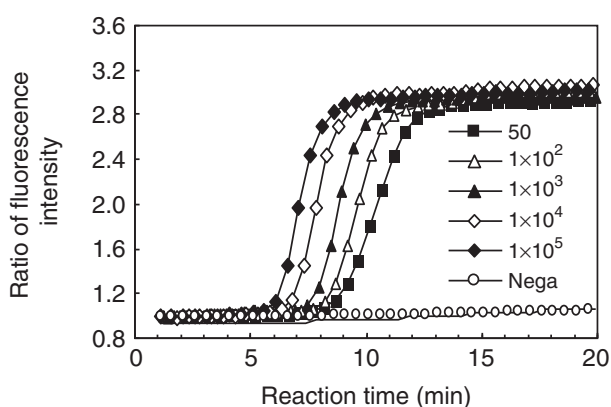

C

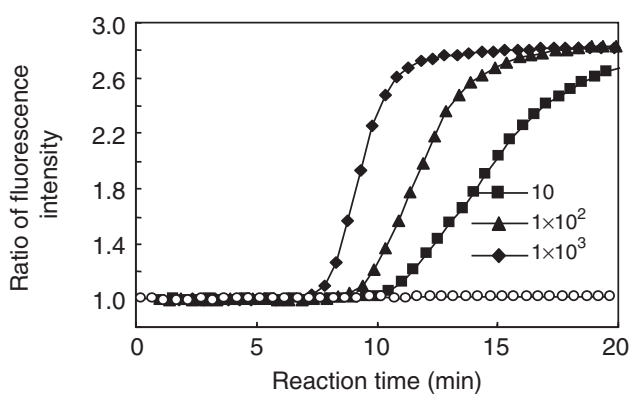

D

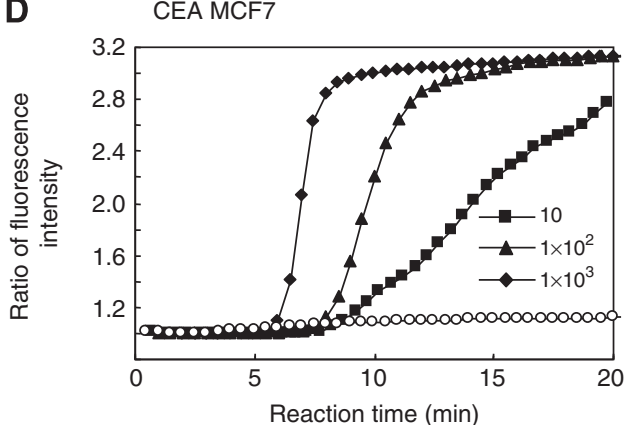

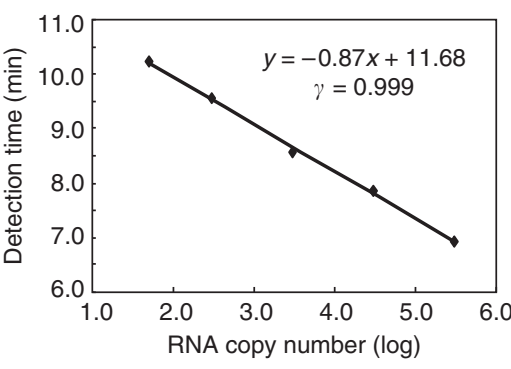
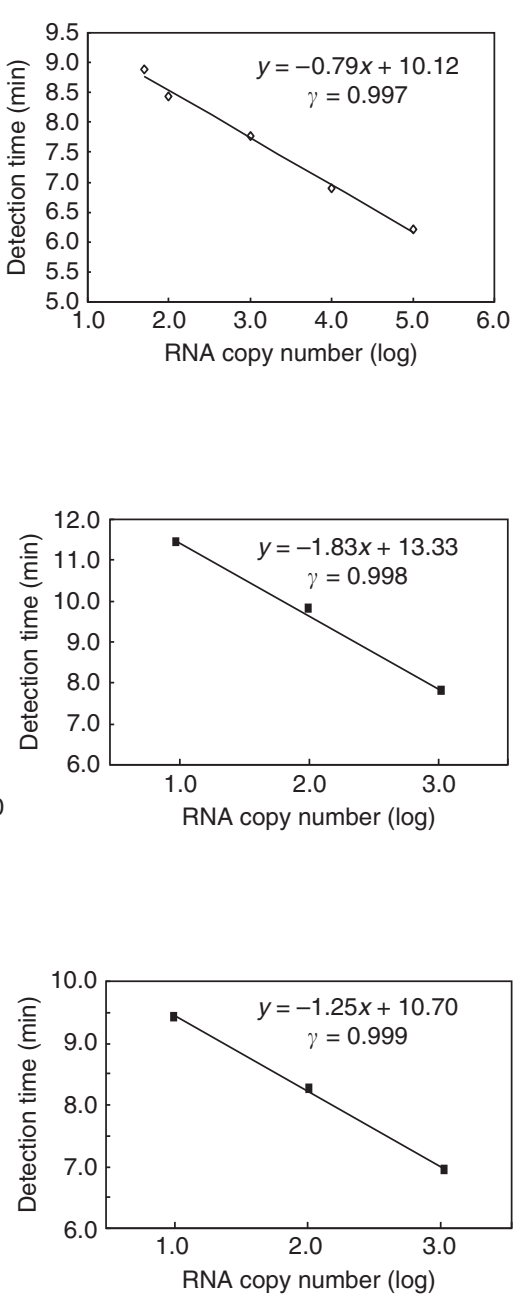

Figure 2 Sensitivity tests of the TRC method using standard RNA and MCF7 cells. Sensitivities of TRC tests for CKI9 and CEA mRNA were examined using the standard RNA samples $(\mathbf{A}, \mathbf{B})$ and MCF7 cell lines $(\mathbf{C}, \mathbf{D})$. Serial dilution of standard RNA of CKI9 (A: from 50 to $\left.3 \times 10^{5}\right)$ and CEA (B: from 50 to $I \times 10^{5}$ ) were used for TRC tests. Serial dilution of CKI9 and CEA-positive MCF7 cells ( from 10 to $I \times 10^{3}$ ) were mixed with PBMC $\left(10^{7}\right.$ cells), and CKI9 mRNA (C) and CEA mRNA (D) were measured using the TRC tests.

sensitivities in the intraoperative $(57.1 \%)$ and permanent tests $(63.6 \%)$. In the validation set, sensitivities of the single marker groups of CK19 and CEA were lower than the CK19/CEA double markers (Table 2B). When compared with the intraoperative test, sensitivities were $95.5 \%$ in CK19, 68.2\% in CEA and $100.0 \%$ in CK19/CEA. In comparison with the permanent pathological test, they were recorded at $62.8 \%$ in CK19, $77.1 \%$ in CEA and $97.1 \%$ in CK19/CEA. In contrast, specificities of these groups showed high levels in the intraoperative test $99.2 \%$ in CK19, 90.2\% in CEA and CK19/CEA) and the permanent test (100.0\% in CK19, $99.2 \%$ in CEA and CK19/CEA). These results suggest that the TRC test with CK19/CEA double markers showed high sensitivity and specificity when compared with the permanent pathological tests.

Furthermore, we examined whether the TRC test can distinguish the micrometastasis and macrometastasis in histologically positive SLNs. By setting up new cut offs depending on the size of 
Table I Characteristics of patients in the training and validation sets

\begin{tabular}{|c|c|c|c|c|}
\hline Variables & $\begin{array}{l}\text { No. of } \\
\text { patients, } \\
n=|3|\end{array}$ & $\begin{array}{l}\text { Training } \\
\text { sets, } \\
n=50(\%)\end{array}$ & $\begin{array}{l}\text { Validation } \\
\text { sets, } \\
n=8 \text { I (\%) }\end{array}$ & $\begin{array}{l}P \text { - } \\
\text { value }\end{array}$ \\
\hline Age & & $57.0 \pm 15.7^{\mathrm{a}}$ & $55.7 \pm 14.4^{\mathrm{a}}$ & 0.631 \\
\hline \multicolumn{5}{|l|}{ Sex } \\
\hline Female & $13 \mid$ & $50(100.0)$ & $81(100.0)$ & \\
\hline Male & 0 & $0(0.0)$ & $0(0.0)$ & \\
\hline \multicolumn{5}{|l|}{ Menopausal status } \\
\hline Pre & 60 & $20(40.0)$ & $40(49.4)$ & 0.563 \\
\hline Post & 69 & $29(58.0)$ & $40(49.4)$ & \\
\hline Unknown & 2 & I (2.0) & I (I.2) & \\
\hline \multicolumn{5}{|l|}{ Primary tumour } \\
\hline Tis & 10 & $6(12.0)$ & $4(4.9)$ & 0.261 \\
\hline $\mathrm{TI}$ & 59 & $20(40.0)$ & $40(49.4)$ & \\
\hline $\mathrm{T} 2$ & 59 & $24(48.0)$ & $35(43.2)$ & \\
\hline T3 & 2 & $0(0.0)$ & $2(2.5)$ & \\
\hline \multicolumn{5}{|l|}{ Histopathological type } \\
\hline Invasive ductal carcinoma & 117 & $41(82.0)$ & $76(93.9)$ & 0.091 \\
\hline $\begin{array}{l}\text { Invasive lobular } \\
\text { carcinoma }\end{array}$ & 4 & $3(6.0)$ & I (I.2) & \\
\hline $\mathrm{DCIS}$ & 10 & $6(12.0)$ & $4(4.9)$ & \\
\hline \multicolumn{5}{|l|}{ Stage } \\
\hline 0 & 10 & $6(12.0)$ & $4(4.9)$ & 0.322 \\
\hline I & 42 & $16(32.0)$ & $26(32.1)$ & \\
\hline 2 & 79 & $28(56.0)$ & $51(63.0)$ & \\
\hline
\end{tabular}

Abbreviation: DCIS = ductal carcinoma in situ. ${ }^{\text {amean }} \pm$ s.d.

metastases, we were able to distinguish between the micro- and macrometastasis. These cutoff levels were 6146 copies for CK19 and 2207 copies for CEA, and they were determined by being based on the mean +2 s.d. copy number of the micrometastatic group. The accuracy of the TRC test for detection of micro- or macrometastasis was $54.3 \%$ in the CK19 marker, $63.0 \%$ in the CEA marker and 91.3\% in the CK19/CEA markers (Table 3). These results suggested that double markers of CK19 and CEA are useful to distinguish between micro- and macrometastasis.

\section{Discordant cases}

In all patients combined the training and validation, sensitivity, specificity and concordance rates of TRC with CK19/CEA double markers to permanent pathological tests were 97.8\%, 99.5\% and $99.2 \%$, respectively (Table $4 \mathrm{~A}$ ). Among these results, two discordant cases were observed. One case was TRC negative and histopathology positive. In this case, CK19 mRNA-positivity was demonstrated by a TRC assay of residual serial sections of the same block. The other case was TRC-positive and histopathologynegative. Here, micrometastasis was observed by the histopathological serial sections of the same block. After correction of these two cases, the final sensitivity, specificity and concordance rates of CK19/CEA to the permanent pathological tests rose to $100 \%$ (Table 4B).

\section{DISCUSSION}

In the present study, we demonstrated that a novel rapid diagnosis of SLN metastasis by a TRC method using double genetic markers CK19/CEA mRNA showed the high sensitivity, specificity and concordance rates to permanent histopathological tests in the training and validation sets.
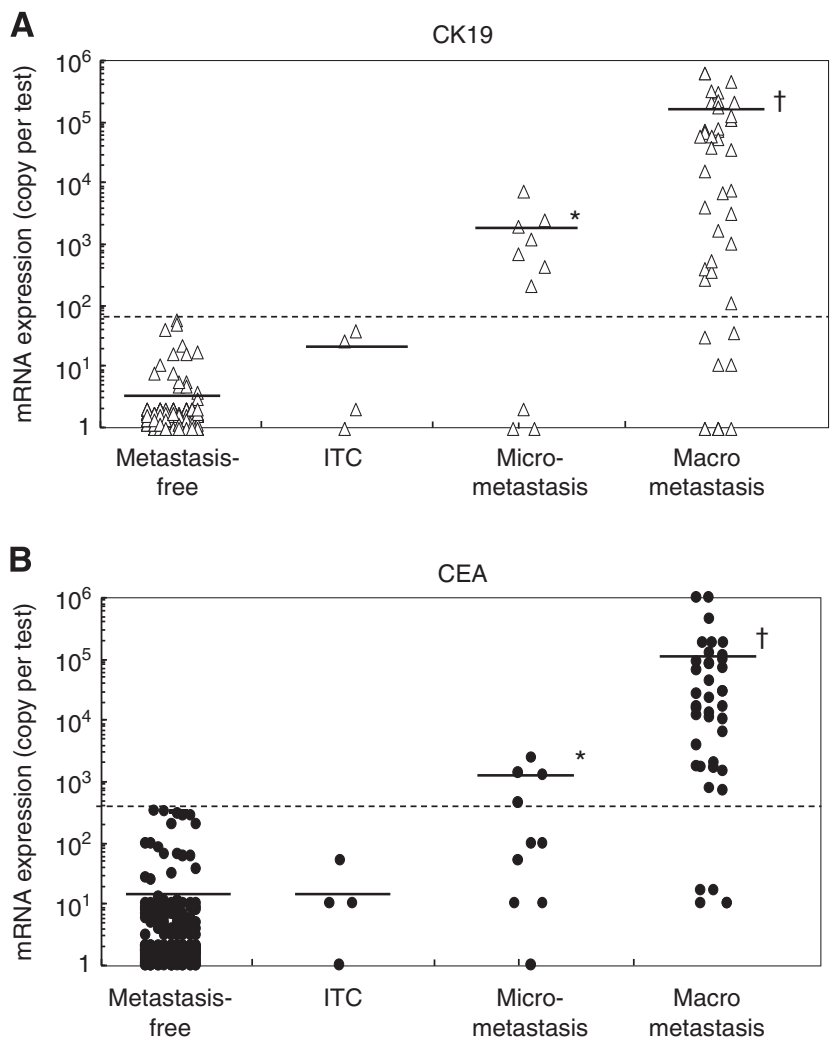

Figure 3 Cytokeratin 19 and CEA copy numbers as determined by the TRC test and metastasis size. Copy numbers of CKI9 $(\mathbf{A})$ and CEA mRNA (B) were plotted in the metastasis-free group $(n=213)$, the ITC group $(n=4)$, the micrometastasis group $(n=10)$ and the macrometastasis group $(n=36)$. The dotted lines show the cutoff levels of CKI9 mRNA (6I copy/ test) and CEA mRNA (329 copy/test). Solid lines show the mean levels of CK 19 and CEA mRNA in each metastatic group. ${ }^{*} P<0.01$ (metastasis-free, ITC vs micrometastasis ), ${ }^{\dagger} P<0.0$ I (metastasis-free, ITC, micrometastasis vs macrometastasis).

Diagnosis of accurate nodal staging is important in the selection of the patients who need adjuvant chemotherapy. To supplement the low sensitivity of intraoperative conventional histopathology, several studies have looked at molecular methods as a means for detecting metastases in SLN (Kurosumi et al, 2007). Two commercially available systems, the GeneSearch BLN assay and one-step nucleic acid amplification (OSNA) assay, have been reported previously as rapid intraoperative methods to detect SLNs in breast cancer patients (Julian et al, 2008; Tamaki et al, 2009). Another novel molecular system, the TRC system, is of interest. This is an RNA direct amplification system based on amplification of the isothermal RNA sequence in the presence of an INAF DNA probe, and the progress of amplicon production can be monitored in real time by measuring the fluorescence intensity of the reaction mixture. The TRC test is performed under a constant temperature $\left(43^{\circ} \mathrm{C}\right)$ without any need for the three steps (denaturing, annealing and extension) of thermal cycling required for PCR. Therefore, the reaction itself is completed in only $20 \mathrm{~min}$, and even if we include RNA elution, the test can be completed within 30-40 min. The rapidity and simplicity of the TRC technique is superior to the usual RT-PCR format. Previously, the usefulness of the TRC assay for molecular diagnosis of free tumour cells in peritoneal lavage fluid of gastric cancer patients has been reported (Fujiwara et al, 2007; Ohashi et al, 2007). We have also demonstrated that the detection of CEA mRNA in peritoneal washings by TRC provides a useful and rapid genetic diagnosis for the prediction of peritoneal recurrence in colorectal 
Table 2 Comparison of TRC and pathological tests in (A) training and (B) validation sets

(A)

\begin{tabular}{|c|c|c|c|c|c|c|}
\hline $\begin{array}{l}\text { TRC test } \\
(n=109)\end{array}$ & \multicolumn{3}{|c|}{ Intraoperative pathological test } & \multicolumn{3}{|c|}{ Permanent pathological test } \\
\hline CEA & $57.1(4 / 7)$ & $97.0(99 / 102)$ & $94.5(103 / 109)$ & $63.6(7 / 11)$ & $100.0(98 / 98)$ & $96.3(105 / 109)$ \\
\hline CKI9 and/or CEA & $100.0(7 / 7)$ & $96.1(98 / 102)$ & $96.3(105 / 109)$ & $100.0(\mid 1 / / 1)$ & $100.0(98 / 98)$ & $100.0(109 / 109)$ \\
\hline
\end{tabular}

(B)

\begin{tabular}{|c|c|c|c|c|c|c|}
\hline $\begin{array}{l}\text { TRC test } \\
(n=155)\end{array}$ & \multicolumn{3}{|c|}{ Intraoperative pathological test } & \multicolumn{3}{|c|}{ Permanent pathological test } \\
\hline CEA & $68.2(15 / 22)$ & $90.2(120 / 133)$ & $87.1(135 / 155)$ & $77.1(27 / 35)$ & $99.2(119 / 120)$ & $94.2(146 / 155)$ \\
\hline CK19 and/or CEA & $100.0(22 / 22)$ & $90.2(120 / 133)$ & $91.6(142 / 155)$ & $97.1(34 / 35)$ & $99.2(119 / 120)$ & $98.7(153 / 155)$ \\
\hline
\end{tabular}

Abbreviations: CEA = carcinoembryonic antigen; CKI9 = cytokeratin 19;n= number of SLN (sentinel lymph node); TRC = transcription concerted reaction.

Table 3 Relationship of TRC test and metastasis classification by permanent pathological test

\begin{tabular}{lccc}
\hline $\begin{array}{l}\text { TRC test } \\
(\boldsymbol{n}=\mathbf{4 6})\end{array}$ & $\begin{array}{c}\text { Sensitivity to } \\
\text { micrometastasis, } \\
\%(\boldsymbol{n}=\mathbf{1 0})\end{array}$ & $\begin{array}{c}\text { Sensitivity to } \\
\mathbf{m a c r o m e t a s t a s i s ,} \\
\%(\boldsymbol{n}=\mathbf{3 6})\end{array}$ & $\begin{array}{c}\text { Accuracy, } \\
\%(\boldsymbol{n}=\mathbf{4 6})\end{array}$ \\
\hline CK19 & $70.0(7 / 10)$ & $50.0(18 / 36)$ & $54.3(25 / 46)$ \\
CEA & $40.0(4 / 10)$ & $69.4(25 / 36)$ & $63.0(29 / 46)$ \\
CK19 and/or CEA & $90.0(9 / 10)$ & $91.7(33 / 36)$ & $91.3(42 / 46)$ \\
\hline
\end{tabular}

Abbreviations: CEA = carcinoembryonic antigen; CKI9 = cytokeratin 19; TRC = transcription concerted reaction.

cancer patients (Hayama et al, 2007). However, until recently, the fact that the commercially available TRC reagent only detected CEA mRNA has meant that this system could not be applied to SLN in breast cancer patients.

Regarding the marker of the breast cancer cell, Tsujimoto et al (2007) reported that 20 cases $(2.2 \%)$ of 896 breast cancer patients are CK19 negative (Tsujimoto et al, 2007). We have also confirmed that about $2.0 \%$ of breast cancer patients did not express the CK19 mRNA in primary tissue (data not shown). Furthermore, recently it has been reported that cancer stem cells are often characterised by down regulation of epithelial markers including cytokeratin (Pantel et al, 2008). If only the single marker CK19 mRNA is used, there is a risk that certain highly aggressive cancer stem cells may avoid diagnosis. To resolve this problem, we selected double markers CK19 and CEA mRNA for detection of metastatic SLNs. It has been reported that high expression of CEA mRNA is detectable in lymph nodes with metastatic breast cancer (Mitas et al, 2001). Ghaffari et al (2006) reported that CEA mRNA showed 95\% sensitivity for breast cancers and $100 \%$ sensitivity for metastatic lymph nodes, and Kataoka et al (2000) applied the CEA mRNA for the detection of SLNs (Kataoka et al, 2000). By selecting double markers in our study, false-negatives were reduced and this resulted in the high sensitivities to the permanent pathological test ( $100 \%$ in the training set and $97.1 \%$ in the validation set). The specificities of CK19 and CEA mRNA to the permanent pathological test were $100 \%$ in both the training and validation tests, and these levels were higher than that of the CK19 and CEA mRNA single marker groups. Positive and negative concordance rates between TRC and the permanent pathological tests were $100 \%$ in the training set and $99.2 \%$ in the validation set. Recently, the commercially available alternatives for rapid molecular detection of SLN, the OSNA assay (Sysmex, Kobe, Japan), have been applied for clinical diagnosis. In the OSNA assay, which used the CK19 single marker, it was reported that in an examination of 346 ALNs from 32 patients, sensitivity was $96.3 \%$, specificity was $94.7 \%$ and the concordance rate was $94.8 \%$ (Visser et al, 2008). In an analysis of 343 SLNs from 93 breast cancer patients, similar results were reported, which is sensitivity of $98.1 \%$, specificity of $90.8 \%$ and a concordance rate of $91.8 \%$ (Schen et al, 2009). From these results it is clear that the TRC test using CK19 and CEA mRNA showed high sensitivity and specificity as compared with the OSNA tests.

Quantifiability of the diagnostic method of SLN metastasis is important because lymph nodes with ITC were considered negative based on the concordance of the UICC 6th and AJCC 6th edited TNM classification. Our results showed that the TRC method is helpful in the quantification of metastasis size. By using the double markers of CEA and CK19, the TRC test enables division of micrometastasis and macrometastasis with $91.3 \%$ accuracy. The TRC assay can be performed and interpreted by a trained technician without the need for a pathologist. Furthermore, the assay can enable an evaluation of all cellular material from the tissues to be obtained. In the future, we are planning to use whole SLN for this test in order to eliminate the sampling error in the portions dedicated to the assay. These advantages may also support the clinical application of the TRC method. To the best of our knowledge, this is the first validated study to demonstrate the usefulness of the TRC assay as an intraoperative molecular diagnosis for detection of metastasis of SLN in breast cancer patients.

In this study, we experienced two cases that showed discrepancies between the TRC and histopathological test. However, the results of the IHC staining of the serial sections of the same residual block, made it clear that this disagreement is related to the location of the SLN metastasis. As the TRC assay is applicable not only to the tissue sections but also the whole SLNs, we do not consider these disagreements to be significant.

In conclusion, we have developed a new CK19 reagent for the TRC assay, and demonstrated that CK19 and CEA mRNA detection with the TRC test is a useful tool for accurate and rapid intraoperative molecular diagnosis of SLN metastasis in patients with breast cancer. 
Table 4 Comparison of TRC and pathological tests in combined sets of training and validation (A) before and (B) after reexamination of the disagreement samples

(A)

\begin{tabular}{|c|c|c|c|c|c|c|}
\hline \multirow[b]{2}{*}{ TRC test $(n=264)$} & \multicolumn{3}{|c|}{ Intraoperative pathological test } & \multicolumn{3}{|c|}{ Permanent pathological test } \\
\hline & $\begin{array}{l}\text { Sensitivity, } \\
\%(n=29)\end{array}$ & $\begin{array}{l}\text { Specificity, } \\
\%(n=235)\end{array}$ & $\begin{array}{c}\text { Concordance } \\
\text { rates, } \%(n=264)\end{array}$ & $\begin{array}{c}\text { Sensitivity, } \\
\%(n=46)\end{array}$ & $\begin{array}{l}\text { Specificity, } \\
\%(n=218)\end{array}$ & $\begin{array}{c}\text { Concordance } \\
\text { rates, } \%(n=264)\end{array}$ \\
\hline CEA & $65.5(19 / 29)$ & $93.2(219 / 235)$ & $90.2(238 / 264)$ & $73.9(34 / 46)$ & $99.5(217 / 218)$ & $95.1(251 / 264)$ \\
\hline CKI9 and/or CEA & $100.0(29 / 29)$ & $92.8(218 / 235)$ & $93.6(247 / 264)$ & $97.8(45 / 46)$ & $99.5(217 / 218)$ & $99.2(262 / 264)$ \\
\hline
\end{tabular}

(B)

Intraoperative pathological test

\begin{tabular}{|c|c|c|c|c|c|c|}
\hline TRC test $(n=264)$ & $\begin{array}{l}\text { Sensitivity, } \\
\%(n=29)\end{array}$ & $\begin{array}{l}\text { Specificity, } \\
\%(n=235)\end{array}$ & $\begin{array}{c}\text { Concordance } \\
\text { rates, } \%(n=264)\end{array}$ & $\begin{array}{l}\text { Sensitivity, } \\
\%(n=47)\end{array}$ & $\begin{array}{l}\text { Specificity, } \\
\%(n=2 \mid 7)\end{array}$ & $\begin{array}{c}\text { Concordance rates, } \\
\%(n=264)\end{array}$ \\
\hline CKI9 & $96.6(28 / 29)$ & $98.3(23 \mid / 235)$ & 98.1 (259/264) & $68.0(32 / 47)$ & $100.0(217 / 217)$ & $94.3(249 / 264)$ \\
\hline CEA & $65.5(19 / 29)$ & $93.2(219 / 235)$ & $90.2(238 / 264)$ & $74.5(35 / 47)$ & $100.0(217 / 217)$ & $95.5(252 / 264)$ \\
\hline CKI9 and/or CEA & $100.0(29 / 29)$ & $92.3(217 / 235)$ & $93.2(246 / 264)$ & $100.0(47 / 47)$ & $100.0(217 / 217)$ & $100.0(264 / 264)$ \\
\hline
\end{tabular}

Abbreviations: CEA = carcinoembryonic antigen; CKI9 = cytokeratin 19; $n=$ number of SLN (sentinel lymph node); TRC $=$ transcription concerted reaction

\section{ACKNOWLEDGEMENTS}

We thank the staff of the clinical pathological department in Teikyo hospital for their excellent work. A grant-in aid was provided for Scientific Research (C) (No. 21591734)

\section{REFERENCES}

Cote RJ, Peterson HF, Chaiwun B, Gelber RD, Goldhirsch A, CastiglioneGertsch M, Gusterson B, Neville AM, International Breast Cancer Study Group (1999) Role of immunohistochemical detection of lymph-node metastases in management of breast cancer. Lancet 354: 896-900

Ferrari A, Rovera F, Dionigi P, Limonta G, Marelli M, Besana CI, Bianchi V, Vanoli C, Dionigi R (2006) Sentinel lymph node biopsy as the new standard of care in the surgical treatment for breast cancer. Expert Rev Anticancer Ther 6: 1503-1515

Fisher ER, Anderson S, Redmond C, Fisher B (1993) Pathologic findings from the National Surgical Adjuvant Breast Project protocol B-06:10-year pathologic and clinical prognostic discrimination. Cancer 71: 2507-2514

Fujiwara Y, Doki Y, Taniguchi H, Shoma I, Takiguchi S, Miyata H, Yamasaki M, Monden M (2007) Genetic detection of free cancer cells in the peritoneal cavity of the patients with gastric cancer: present status and future perspective. Gastric Cancer 10: 197-204

Ghaffari SR, Sabokbar T, Tahmasebi S, Dastan J, Shorakae S, Moradi A, Tirgari F, Mohagheghi MA, Mosavi-Jarrahi A (2006) Combining mammglobin and carcinoembryonic mRNA markers for early detection of micrometastases from breast cancer-a molecular study of 59 patients. Asian Pacific J Cancer Prev 7: 396-398

Giuliano AE, Hunt KK, Ballman KV, Beitsch PD, Whitworth PW, Blumencranz PW, Leitch AM, Saha S, McCall LM, Morrow M (2011) Axillary dissection vs no axillary dissection in women with invasive breast cancer and seninel node metastasis: a randomized clinical trial. JAMA 305: 569-575

Hayama T, Iinuma H, Watanabe $\mathrm{T}$ (2007) Rapid genetic diagnosis with transcription concerned reaction system for peritoneal recurrence and survival in colorectal cancer patients. Oncol Rep 18: 779-784

Julian TB, Blumencranz P, Deck K, Whitworth P, Berry DA, Berry SM, Rosenberg A, Chagpar AB, Reintgen D, Beitsch P, Simmons R, Saha S (2008) Novel intraoperative molecular test for sentinel lymph node metastases in patients with early-stage breast cancer. J Clin Oncol 26: 3338-3345 from the Japanese Ministry of Education, Science, Sports and Culture.

Supplementary Information accompanies the paper on British Journal of Cancer website (http://www.nature.com/bjc)
Kataoka A, Mori M, Sadanaga N, Ueo H, Tsuji K, Rai Y, Barnard GF, Sugiuchi K (2000) RT-PCR detection of breast cancer cells insentinel lymph modes. Int J Oncol 16: 1147-1152

Kim T, Goioano AS, Lyman GH (2006) Lymphatic mapping and sentinel lymph node biopsy in early-stage breast carcinoma. Cancer 106: 4-16

Kurosumi M, Takei H (2007) Significance and problems of histopathological examination and utility of real-time reverse transcriptase-polymerase chain reaction method for the detection of sentinel lymph node metastasis in breast cancer. Breast cancer 14: 342-349

Lyman GH, Giuliano AE, Somerfield MR, Benson III AB, Bodurka DC, Burstein HJ, Cochran AJ, Cody III HS, Edge SB, Galper S, Hayman JA, Kim TY, Perkins CL, Podoloff DA, Sivasubramaniam VH, Turner RR, Wahl R, Weaver DL, Wolff AC, Winer EP, American Society of Clinical Oncology (2005) American Society of Clinical Oncology guideline recommendations for sentinel lymph node biopsy in early-stage breast cancer. J Clin Oncol 23: 7703-7720

Mansel RE, Fallowfield L, Kissin M, Goyal A, Newcombe RG, Dixon JM, Yiangou C, Horgan K, Bundred N, Monypenny I, England D, Sibbering M, Abdullah TI, Barr L, Chetty U, Sinnett DH, Fleissig A, Clarke D, Ell PJ (2006) Randomized multicenter trial of sentinel node biopsy versus standard axillary treatment in operable breast cancer: the ALMANAC Trial. I Nat Cancer Inst 98: 599-609

Mitas M, Mikhitarian K, Walters C, Baron PL, Elliott BM, Brothers TE Robison JG, Metcalf JS, Palesch YY, Zhang Z, Gillanders WE, Cole DJ (2001) Quantitative real-time RT-PCR detection of breast cancer mictometastasis using a multigene marker panel. Int $J$ Cancer 93: 162-171

Moore MP, Kinne DW (1997) Axillary lymphadenectomy: a siagnostic and therapeutic procedure. J Surg Oncol 66(1): 2-6

NCCN (2011) National Comprehensive Cancer Network Clinical Practice Guidelines in Oncology. Breast Cancer. Ver2, 2011 (http://www.nccn.org/ professionals/ physician_gls/PDF/breast.pdf)

Nissan A, Jager D, Roystacher M, Prus D, Peretz T, Eisenberg I, Freund HR Scanlan M, Ritter G, Old LJ, Mitrani-Rosenbaum S (2006) Multimarker RT-PCR aasay for the detection of minimal residual disease in sentinel lymph nodes of breast cancer patients. Br J Cancer 94: 681-685 
Ohashi N, Nakanishi H, Kodera Y, Ito S, Mochizuki Y, Koike M, Fujiwara M, Yamamura Y, Takematsu M, Nakano A, Kato T (2007) Intraoperative quantitative detection of CEA mRNA in the peritoneal lavage of gastric cancer patients with transcription reverse-transcription concerted (TRC) method. A comparative study with real-time quantitative RT-PCR. Anticancer Res 27: 2769-2278

Pantel K, Brakenhoff RH, Brandt B (2008) Detection, clinical relevance and specific biological properties of disseminating tumor cells. Nat Rev Cancer 8: $329-340$

Purushortham AD, Upponi S, Klevesath MB, Bobrow L, Millar K, Myles JP, Duffy SW (2005) Morbidity after sentinel lymph node biopsy in primary breast cancer. J Clin Oncol 23: 4312-4321

Schen S, Maass N, Bauserschlag DO, Carstensen MH, Loning T, Roder C, Batic O, Jonat W, Tiemann K (2009) One-step nucleic acid amplification -a molecular method for the detection of lymph node metastases in breast cancer patients; results of the German study group. Virchows Arch 454: $203-210$

Tamaki Y, Akiyama F, Iwase T, Kaneko T, Tsuda H, Sato K, Ueda S, Mano M, Masuda N, Takeda M, Tsujimoto M, Yoshidome K, Inaji H, Nakajima H, Komoike Y, Kataoka TR, Nakamura S, Suzuki K, Tsugawa K, Wakasa K, Okino T, Kato Y, Noguchi S, Matsuura N (2009) Molecular detection of lymph node metastases in breast cancer patients: results of a multicenter trial using the ONE-step nucleic acid amplification assay. Clin Cancer Res 15: 2879-2884

Tanis PJ, Boom RPA, Koops HS, Faneyte IF, Peterse JL, Nieweg OE, Rutgers EJT, Tiebosch ATMG, Kroon BBR (2001) Frozen section investigation of the sentinel node in malignant melanoma and breast cancer. Ann Surg Oncol 8: 222-226

Torrenga H, Rahusen FD, Meijer S, Borgstein PJ, van Diest PJ (2001) Sentinel node investigation in breast cancer: detailed analysis of the yield from step sectioning and immunohistochemistry. J Clin Pathol 54: $550-552$

Tsujimoto M, Nakabayashi K, Yoshidome K, Kaneko T, Iwase T, Akiyama F, Kato Y, Tsuda H, Ueda S, Sato K, Tamaki Y, Noguchi S, Kataoka TR, Nakajima H, Komoike Y, Inaji H, Tsugawa K, Suzuki K, Nakamura S, Daitoh M, Otomo Y, Matsuura N (2007) One-step nucleic acid amplification for intraoperative detection of lymph node metastasis in breast cancer patients. Clin Cancer Res 13: 4807-4816

van Diest PJ, Peterse HL, Borgstein PJ, Hoekstra O, Meijer CJ (1999) Pathological investigations of sentinel lymph nodes. Eur J Nucl Med 26: S43-S49

Veronesi U, Paganelli G, Viale G, Luini A, Zurrida S, Galimberti V, Intra M, Veronesi P, Robertson C, Maisonneuve P, Renne G, De Cicco C, De Lucia F, Gennari R (2003) A randomized comparison of sentinel-node biopsy with routine axillary dissection in breast cancer. $N$ Engl Med 349: 546-553

Visser M, Jiwa M, Horstman A, Brink AATP, Pol RP, van Diest P, Snijders PJF, Meijer CJLM (2008) Intra-operative rapids diagnostic method based on CK19 mRNA expression for the detection of lymph node metastases in breast cancer. Int J Cancer 122: 2562-2567

Weigwlt B, Verduijin P, Bosma AJ, Rutgers EJ, Peterse HL, van't Veer LJ (2004) Detection of metastases in sentinel lymph nodes of breast cancer patients by multiple mRNA markers. Br J Cancer 90: 1531-1537

This work is published under the standard license to publish agreement. After 12 months the work will become freely available and the license terms will switch to a Creative Commons Attribution-NonCommercial-Share Alike 3.0 Unported License. 